\title{
Variable larval growth in a coral reef fish
}

\author{
Steven P. Searcy ${ }^{*}$, Su Sponaugle ${ }^{* *}$ \\ Marine Sciences Research Center, State University of New York at Stony Brook, Stony Brook, New York 11794-5000, USA
}

\begin{abstract}
Understanding the functional linkages between the pelagic and demersal stages of marine organisms is a central goal in ecology. To better understand events that occurred during the larval period as well as their initial influence on juvenile traits, we examined individual level variation in early life-history traits (larval and early juvenile otolith growth rates, size-at-age, and larval duration) of 3 seasonal cohorts of the common coral reef fish Thalassoma bifasciatum (Bloch) (Labridae). Juveniles were collected at regular intervals (every second day) for 2 wk following their first appearance on the nearshore reefs of Barbados, West Indies. Otolith analysis indicated that each cohort exhibited a broad range of larval traits. Individuals with shorter larval durations had faster otolith growth and settled at relatively smaller sizes (based on otolith length and standard length) than larvae with longer larval durations, which exhibited slower otolith growth rates. Despite the range in larval durations for $T$. bifasciatum, otolith growth records revealed no evidence for delay of metamorphosis. Instead, the range in larval durations is likely to be the result of a variable pelagic environment influencing growth rates. Because metamorphosis in this species is an energetically costly non-feeding ( 3 to $5 \mathrm{~d}$ ) period, we propose that successful metamorphosis requires a minimum energy reserve. Slower growers may need to remain in the plankton longer (consequently attaining larger sizes) to obtain this minimum condition. Variability in early life-history traits also occurred among the seasonal cohorts. Despite differences in patterns of larval otolith growth, mean larval duration was similar for the 2 fall cohorts ( 57 and $55 \mathrm{~d}$ ), but much shorter for the spring cohort (42 d). Such inter-cohort variability in early life-history traits suggests a variable pelagic environment. In contrast to the larval period, juvenile growth rates were much less variable within and among cohorts, reflecting a more constant physical and biological environment on the reef.
\end{abstract}

KEY WORDS: Coral reef fish · Early life-history traits $\cdot$ Juvenile growth $\cdot$ Larval growth $\cdot$ Growth plasticity · Otolith · Pelagic larval duration · Condition at settlement · Thalassoma bifasciatum

\section{INTRODUCTION}

In many benthic marine organisms, settlement to the juvenile/adult habitat divides the life history into a pelagic larval phase and demersal adult phase. Studies of temperate fishes recently have placed an emphasis on the role of larval traits (e.g. age-at-settlement,

\footnotetext{
Present addresses:

*Department of Marine, Earth, and Atmospheric Sciences, North Carolina State University, Raleigh, North Carolina 27695-8208, USA. E-mail: spsearcy@unity.ncsu.edu

** Division of Marine Biology and Fisheries, Rosenstiel School of Marine and Atmospheric Science, University of Miami, Florida, Miami 33149-1098, USA
}

growth rates, length-at-age) in the subsequent dynamics of juvenile growth and survival (Chambers \& Leggett 1992, Bertram et al. 1993), however, similar issues have received little attention in studies of tropical (coral reef) fishes. Due to high predation on the youngest recruits (e.g. Hixon 1991), larval traits at settlement may influence initial survival on the reef. If such traits are propagated to older juveniles, they may also impact later competitive abilities and susceptibility to predators (reviewed in Sogard 1997). Analysis of the natural variability of larval traits at settlement should contribute to our understanding of events occurring in the pelagic larval phase, and how these events or processes impact subsequent juvenile traits and, ultimately, population dynamics. 
Fishes are ideal subjects in which to examine variability in early life-history traits as the otoliths (ear bones) of many fishes contain a daily record of previous events. Relative otolith growth and length-at-age may be reflected in somatic traits (e.g. Secor \& Dean 1989, Hare \& Cowen 1995). The use of otolith records in field studies has enabled the description of seasonal (Bell et al. 1995, Fowler \& Short 1996), annual (Sponaugle \& Cowen 1994, 1997, Meekan \& Fortier 1996) and geographic differences in early life-history traits such as growth rates and larval duration (Thresher \& Brothers 1989, Wellington \& Victor 1992). These differences may be the result of maternal influence (egg quality: Chambers 1997) and genotype (Chambers \& Leggett 1992), as well as environmental factors such as food availability (Mosegaard et al. 1988, McCormick \& Molony 1992) and temperature (Hovenkamp 1990, Fitzhugh et al. 1997). However, a precursor to understanding such comparisons is the need to document the range of natural variation within a single cohort (McCormick 1994, Fowler \& Short 1996).

Pelagic larval durations (PLD) are variable among recruiting fishes (Fowler 1989, Wellington \& Victor 1992, Sponaugle \& Cowen 1997) as well as invertebrates (Pechenik 1990, Stoner et al. 1996). The lower limit of time spent in the plankton may indicate when larvae are competent to settle, whereas the upper limit may be the result of delayed metamorphosis where larvae are capable of metamorphosis but await the proper settlement cue (e.g. Cowen 1991, Cowen \& Sponaugle 1997, McCormick 1999). Alternatively, larvae may settle upon reaching competency, but as a result of variable precompetent growth, slower growers settle at older ages than relatively faster growers (e.g. Chambers \& Leggett 1987, Bertram et al. 1993). Ultimately, the causes of variation in PLD may be the result of a range of precompetent growth rates, delayed metamorphosis, or both (Cowen 1991, Cowen \& Sponaugle 1997).

Very little is known about how larval traits are translated into juvenile traits once a larva reaches the juvenile/adult habitat. As mortality is often highest for the youngest recruits (e.g. Hixon 1991), size and condition at settlement may be of immediate importance in avoiding selective predation. Although there is little empirical evidence for selective predation on very newly recruited fishes (Bertram \& Leggett 1994, McCormick \& Kerrigan 1996, but see Searcy \& Sponaugle in press), size-selective predation has been detected among older juveniles (reviewed in Sogard 1997). In addition, size differences at settlement may be perpetuated into the juvenile period (Forrester 1990, Bertram 1996). This is potentially important for fishes with size-dominated social hierarchies, as size may determine competitive abilities in obtaining food, space, and ultimately, reproductive success (e.g. Tupper \& Boutilier 1995). Thus, either through selective mortality or influence on competitive abilities, traits at settlement may have a substantial impact on both newly recruited and older juveniles.

Variability in size, age, and growth rates of fish during the larval and juvenile periods may play an important role in population dynamics. Studies examining the range of natural variation in early life-history traits within and among cohorts should help identify traits upon which selection may act, as well as identify how such traits may be influenced by environmental factors. As part of a larger project, this study was designed to examine variation in a number of early lifehistory traits within and among seasonal cohorts of a common coral reef fish, the bluehead wrasse Thalassoma bifasciatum.

\section{MATERIALS AND METHODS}

Study site. Barbados is the easternmost island in the Lesser Antilles and is geographically isolated (140 km to the east of its nearest neighbor; see Fig. 1 of Sponaugle \& Cowen 1996). The predominate current flows northwest at 0.35 to $0.55 \mathrm{~m} \mathrm{~s}^{-1}$, and large-scale circulation appears to be topographically steered along the coasts before being recirculated and continuing downstream (Cowen \& Castro 1994). As Barbados is upstream from other larval sources, it is generally believed that pelagic larvae spawned by island populations are retained in the vicinity of the island and recruit back to the local reefs (Cowen \& Castro 1994, Sponaugle \& Cowen 1996, Cowen et al. 2000).

Study species. Thalassoma bifasciatum the bluehead wrasse, is a common coral-reef fish found throughout the Caribbean. It is a sequential hermaphrodite (protogynous) and spawns daily (Warner \& Robertson 1978, Robertson et al. 1999). The pelagic larval duration is variable (Victor 1986, Sponaugle \& Cowen 1997) and settlement to the reef is pulsed (Sponaugle \& Cowen 1997, Robertson et al. 1999). Larvae settle into the sand and undergo metamorphosis for 3 to $5 \mathrm{~d}$ (Victor 1982). After metamorphosis, recruits emerge from the sand and are found as solitary individuals swimming low in coral crevices (Sponaugle \& Cowen 1997). As they age, individuals school in progressively larger groups higher in the water column (Sponaugle \& Cowen 1997).

Collection methods. We collected juvenile fish in shallow water (1 to $6 \mathrm{~m}$ depth) on reef spurs along the western coast of Barbados. We collected cohorts of Thalassoma bifasciatum during May (Spring cohort), August/September (Fall 1 cohort), and September/ October (Fall 2 cohort), evenly, offshore of Green- 
sleeves, North Bellairs, the Bellairs Research Institute, and Batts Rock (equivalent to Site Nos. 2-3, 4, 6, 8 in Sponaugle \& Cowen 1997). We collected juvenile fish as soon as they emerged from the sand and every other day over 2 wk using SCUBA, hand nets, and the anesthetic Quinaldine. We sampled on different areas of the reef (minimum of $25 \mathrm{~m}$ apart) so that previous collections would not bias later collections. After each sampling excursion, we brought the fish back to the laboratory, where they were immediately preserved in $95 \%$ ethanol.

Otolith analysis. Previous work has validated the daily nature of otolith increment deposition in Thalassoma bifasciatum (Victor 1982). Otoliths of T. bifasciatum have a clear mark corresponding to settlement of the larva onto the reef (validated for another common coral-reef wrasse, Halichoeres bivittatus: Victor 1983). This mark is followed by a wide, unreadable band (representing the period of time during which settlers are buried in the sand undergoing metamorphosis) that ends with an emergence mark, after which daily increment deposition is once again established (Victor 1983). The relationship between fish length and otolith length in T. bifasciatum is strongly correlated (Victor 1986, Masterson et al. 1997, Sponaugle \& Cowen 1997 , Searcy \& Sponaugle in press). Despite this positive relationship, to avoid potential sources of error in backcalculating traits (Thorrold \& Milicich 1990, Fowler \& Short 1996), all comparisons of size and growth use otolith rather than derived somatic characteristics.

Prior to dissection, we recorded the standard length of each fish to the nearest $0.1 \mathrm{~mm}$. Following otolith extraction, we placed fish in a drying oven at $60^{\circ} \mathrm{C}$ for $24 \mathrm{~h}$. Upon removal, the dried fish were allowed to cool for $5 \mathrm{~min}$ and were weighed to the nearest $0.1 \mathrm{mg}$ in a sealed Mettler balance. We dissected out 2 pairs of otoliths, the sagittae and lapilli, from each fish and placed them on microscope slides in medium-viscosity immersion oil for $30 \mathrm{~d}$ to allow clearing and to facilitate reading (Sponaugle \& Cowen 1997). We read the sagittae using a Zeiss transmitted light microscope at 250×, with a rotating polarized filter placed between the light source and the first stage. The microscope image was captured with a frame-grabber and measurements were taken on a computer screen using the OPTIMAS image-analysis system (Version 6.1: OPTIMAS 1996). We analyzed all otoliths along their longest radius from the core to the outer edge, and for each increment in larval and juvenile period we recorded otolith length (radius). From this information we determined larval duration, width of the metamorphic band, juvenile age (post-emergence age), and increment width (proxy for daily growth) during the larval and juvenile periods. For larval duration measurements, we added $2 \mathrm{~d}$ to the total number of pre-settlement increments (reflecting a standard time to hatching: Victor 1982, Sponaugle \& Cowen 1997, Robertson et al. 1999).

Only 1 person read all otoliths. Before measurements were made, all abnormally shaped otoliths, pairs of unequally sized sagittae, and unclear (large portions with no discernable increments) otoliths were discarded $(\sim 15 \%)$. We made 2 independent measures of each otolith. If counts differed by $<5 \%$, then we randomly selected 1 of the readings. If increment counts differed by $>5 \%$, the otolith was read again. If the third count was within $5 \%$ of 1 of the former readings, then we randomly chose 1 of the 2 closest measurements for analysis. Alternatively, if the difference was still $>5 \%$ of the previous readings, we discarded the otolith $(\sim 15 \%)$. To insure that individuals were from the same cohort while allowing a sufficiently high sample size, only fish that emerged during an $8 \mathrm{~d}$ window of recruitment were used in the analysis (total used in analysis, $\mathrm{n}=385$ ).

Data analysis. We divided each cohort into nearly equally sized groups based on pelagic larval duration (PLD) to determine the relationship between larval duration, growth trajectories, and size-at-age. Otolith length-at-age data were not normally distributed, so a natural log-transformation was applied to improve normality and homogeneity of variance (Sokal \& Rohlf 1995). Because of the broad range in larval duration, we analyzed growth both progressively (post-hatch) and hindcast (back from settlement). Progressive larval growth trajectories revealed whether growth patterns diverged from an early age. Hindcast growth trajectories enabled the examination of temporal events that might have influenced the entire cohort.

We used a repeated-measures MANOVA (SYSTAT Version 5.1: Wilkinson 1992) for all comparisons of otolith growth and size-at-age among groups with different PLDs. We compared progressive larval growth and length-at-age among PLD groups using $5 \mathrm{~d}$ intervals. For example, to compare PLD groups of 35 versus $40 \mathrm{~d}$, we compared otolith length on Days 5, 10, 15, 20, 25, 30, 35 and daily otolith growth averaged over the same $5 \mathrm{~d}$ intervals (Days 1-5, 6-10, 11-15, 16-20, 21-25, 26-30, and 31-35). All hindcast growth comparisons compared the $25 \mathrm{~d}$ prior to settlement using 5 d intervals, $0-5,6-10$, 11-15, 16-20, and 21-25 d prior to settlement. MANOVA techniques allow comparisons to be made at the resolution of an individual fish (Chambers \& Miller 1995, Meekan \& Fortier 1996). Comparisons were made between groups with the null hypothesis of no difference. The statistic used was Wilks' $\lambda$ for the interaction term, which is based on sample size, number of groups in the comparison, and number of intervals being analyzed. When group differences were significant, canonical loadings revealed the relative importance of group differences at each interval by increasing in magnitude. 
Thus, the interval with the highest canonical loading contributes the most to the rejection of the null hypothesis (Chambers \& Miller 1995).

Finally, to determine whether post-settlement juvenile growth and length-at-age were similar within PLD subsets and among cohorts, we made comparisons among juveniles that had been on the reef for a minimum of $5 \mathrm{~d}$ (repeated-measures MANOVA). Similarly, we examined otolith length-at-settlement, width of the metamorphic band, and standard length and weight of $<1 \mathrm{~d}$ old (post-emergence) fish to determine the influence of larval duration. Because all groups had unequal sizes, the $T^{\prime}$ method for unplanned comparisons among means was used (Sokal \& Rohlf 1995: Biomstat 3.1). We used a standard ANOVA where only 2 groups were compared.
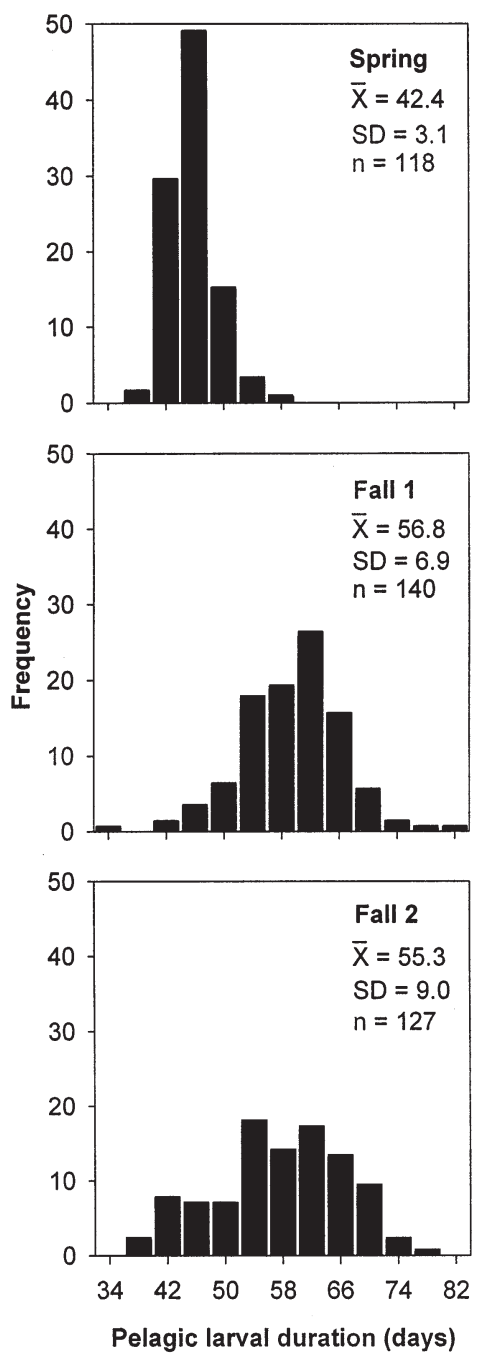

Fig. 1. Thalassoma bifasciatum. Frequency of pelagic larval duration (d) for 3 seasonal cohorts $\bar{X}=$ mean, $\mathrm{SD}=$ standard deviation, $\mathrm{n}=$ sample size for each cohort

\section{RESULTS}

\section{Within-cohort comparisons}

Larval traits

Each seasonal cohort exhibited a range of larval durations (Fig. 1). When larval duration was used to separate groups within each cohort, distinct patterns in otolith growth trajectories became evident. In all cohorts, otolith growth was faster in groups with shorter PLDs than those with longer PLDs (Fig. 2). This trend was significant for all groups in the 2 fall cohorts, but not significant among any groups in the spring cohort (repeated-measures MANOVA: Table 1). In both the Fall 2 and Spring cohorts,
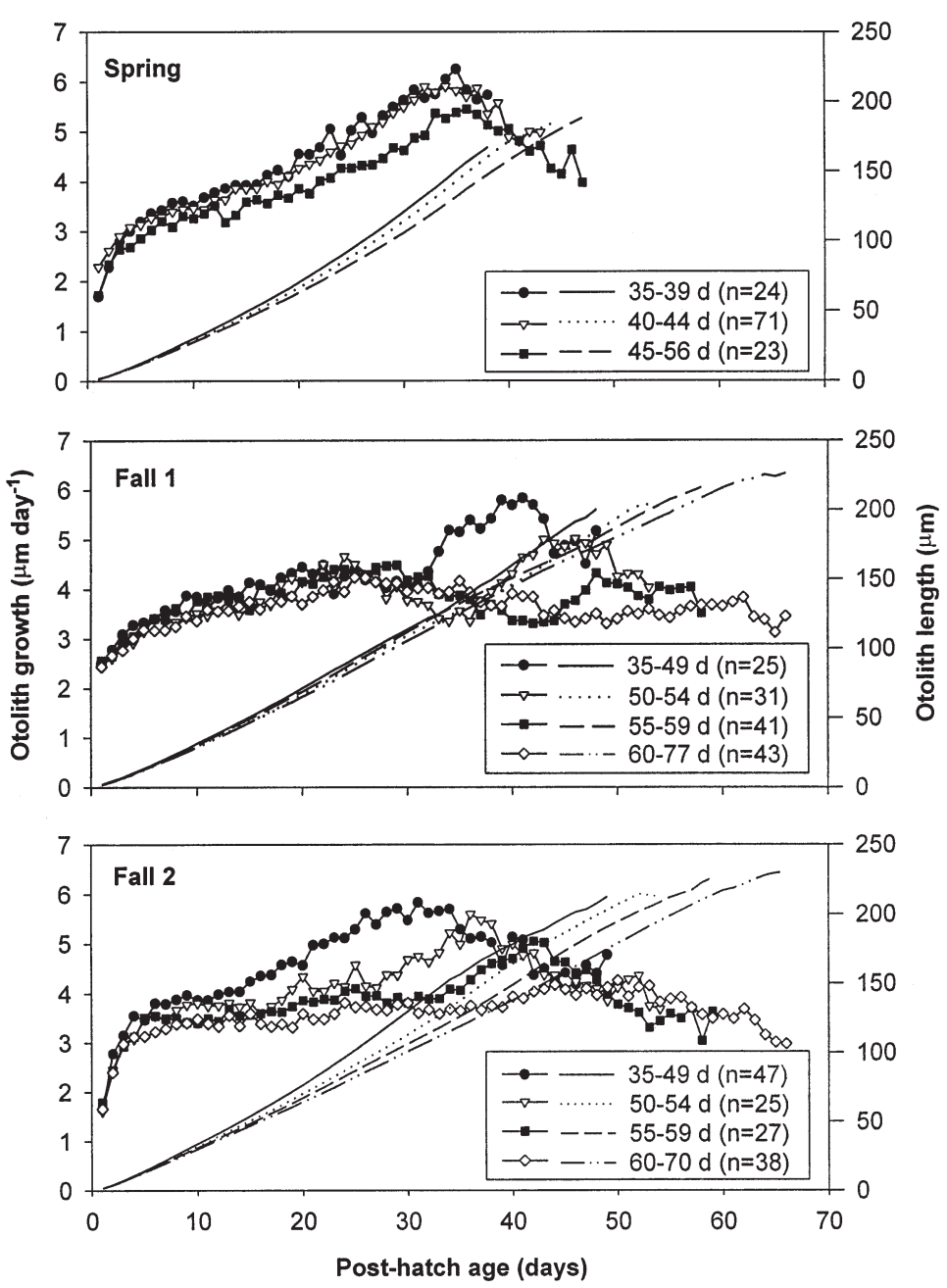

Fig. 2. Thalassoma bifasciatum. Mean progressive larval otolith growth rate (lines with symbols) and otolith length-atage (continuous, dashed, and dotted lines) trajectories for 3 seasonal cohorts. Within each cohort, fish were divided into groups based on pelagic larval duration (PLD) 
Table 1. Thalassoma bifasciatum. Within-cohort comparisons of early life-history traits between shorter (S) and longer (L) pelagic larval duration (PLD) groups using repeated-measures MANOVA and ANOVA ( $T^{\prime}$ method: Sokal \& Rohlf 1995). Where comparisons were significantly different, trend is indicated: $\mathrm{S}>\mathrm{L}=$ group with shorter PLD had larger value; $\mathrm{S}<\mathrm{L}=$ group with shorter PLD had smaller value ${ }^{*},{ }^{* *},{ }^{* * *}$ significant at $\mathrm{p}<0.05, \mathrm{p}<0.01, \mathrm{p}<0.001$, respectively; ns $=$ non-significant at $\mathrm{p}>0.05$

\begin{tabular}{|c|c|c|c|c|c|c|c|}
\hline \multirow[t]{2}{*}{ Cohort } & \multicolumn{2}{|c|}{ Comparisons } & \multicolumn{3}{|c|}{ Repeated measures MANOVA } & \multicolumn{2}{|c|}{ ANOVA ( $T^{\prime}$ method) } \\
\hline & Short PLD & Long PLD & $\begin{array}{c}\text { Progressive } \\
\text { larval otolith } \\
\text { growth }\end{array}$ & $\begin{array}{l}\text { Hindcast } \\
\text { larval otolith } \\
\text { growth }\end{array}$ & $\begin{array}{l}\text { Larval otolith } \\
\text { length-at-age }\end{array}$ & $\begin{array}{l}\text { Otolith length- } \\
\text { at-settlement }\end{array}$ & $\begin{array}{l}\text { Otolith metamorphic } \\
\text { band width }\end{array}$ \\
\hline \multirow[t]{3}{*}{ Spring } & $35-39 d$ & $40-44 \mathrm{~d}$ & ns & $S>L^{*}$ & ns & $\mathrm{S}<\mathrm{L}^{* * *}$ & ns \\
\hline & & $45-56 \mathrm{~d}$ & ns & $\mathrm{S}>\mathrm{L}^{* * *}$ & ns & $\mathrm{S}<\mathrm{L}^{* * *}$ & ns \\
\hline & $40-44 \mathrm{~d}$ & $45-56 \mathrm{~d}$ & ns & $\mathrm{S}>\mathrm{L}^{* * *}$ & ns & $\mathrm{S}<\mathrm{L}^{* * *}$ & ns \\
\hline \multirow[t]{6}{*}{ Fall 1} & $35-49 d$ & $50-54 \mathrm{~d}$ & $\mathrm{~S}>\mathrm{L}^{* * *}$ & ns & $S>L^{*}$ & $\mathrm{~S}<\mathrm{L}^{* * *}$ & ns \\
\hline & & $55-59 \mathrm{~d}$ & $\mathrm{~S}>\mathrm{L}^{* * *}$ & $\mathrm{~S}>\mathrm{L}^{* * *}$ & $\mathrm{~S}>\mathrm{L}^{* * *}$ & $\mathrm{~S}<\mathrm{L}^{* * *}$ & ns \\
\hline & & $60-70 \mathrm{~d}$ & $\mathrm{~S}>\mathrm{L}^{* * *}$ & $\mathrm{~S}>\mathrm{L}^{* * *}$ & $\mathrm{~S}>\mathrm{L}^{* * *}$ & $\mathrm{~S}<\mathrm{L}^{* * *}$ & ns \\
\hline & $50-54 d$ & $55-59 \mathrm{~d}$ & $\mathrm{~S}>\mathrm{L}^{* * *}$ & $\mathrm{~S}>\mathrm{L}^{*}$ & $\mathrm{~S}>\mathrm{L}^{* * *}$ & $\mathrm{~S}<\mathrm{L}^{* * *}$ & ns \\
\hline & & $60-70 \mathrm{~d}$ & $\mathrm{~S}>\mathrm{L}^{* * *}$ & $\mathrm{~S}>\mathrm{L}^{* * *}$ & $\mathrm{~S}>\mathrm{L}^{* * *}$ & $\mathrm{~S}<\mathrm{L}^{* * *}$ & ns \\
\hline & $55-59 \mathrm{~d}$ & $60-70 \mathrm{~d}$ & $\mathrm{~S}>\mathrm{L}^{* *}$ & ns & $\mathrm{S}>\mathrm{L}^{* *}$ & $\mathrm{~S}<\mathrm{L}^{* * *}$ & ns \\
\hline \multirow[t]{6}{*}{ Fall 2} & $35-49 d$ & $50-54 \mathrm{~d}$ & $\mathrm{~S}>\mathrm{L}^{* *}$ & $\mathrm{~S}>\mathrm{L}^{* *}$ & $\mathrm{~S}>\mathrm{L}^{*}$ & $\mathrm{~S}<\mathrm{L}^{* * *}$ & ns \\
\hline & & $55-59 \mathrm{~d}$ & $\mathrm{~S}>\mathrm{L}^{* * *}$ & $\mathrm{~S}>\mathrm{L}^{* *}$ & $\mathrm{~S}>\mathrm{L}^{* * *}$ & $\mathrm{~S}<\mathrm{L}^{* * *}$ & $\mathrm{~S}>\mathrm{L}^{*}$ \\
\hline & & $60-70 \mathrm{~d}$ & $\mathrm{~S}>\mathrm{L}^{* * *}$ & $\mathrm{~S}>\mathrm{L}^{*}$ & $\mathrm{~S}>\mathrm{L}^{* * *}$ & $\mathrm{~S}<\mathrm{L}^{* * *}$ & $\mathrm{~S}>\mathrm{L}^{* *}$ \\
\hline & $50-54 d$ & $55-59 \mathrm{~d}$ & $\mathrm{~S}>\mathrm{L}^{* *}$ & $\mathrm{~ns}$ & $\mathrm{~S}>\mathrm{L}^{* * *}$ & $\mathrm{~S}<\mathrm{L}^{*}$ & $\mathrm{~S}>\mathrm{L}^{* *}$ \\
\hline & & $60-70 \mathrm{~d}$ & $\mathrm{~S}>\mathrm{L}^{* * *}$ & $\mathrm{~S}>\mathrm{L}^{*}$ & $\mathrm{~S}>\mathrm{L}^{* * *}$ & $\mathrm{~S}<\mathrm{L}^{* * *}$ & $S>L^{* * *}$ \\
\hline & $55-59 \mathrm{~d}$ & $60-70 \mathrm{~d}$ & $\mathrm{~S}>\mathrm{L}^{* *}$ & $\mathrm{~S}>\mathrm{L}^{*}$ & $\mathrm{~S}>\mathrm{L}^{* * *}$ & $\mathrm{~S}<\mathrm{L}^{* * *}$ & ns \\
\hline
\end{tabular}

otolith growth trajectories were domed, and in general groups with shorter PLDs had faster otolith growth rates, starting at 5 to $10 \mathrm{~d}$ post-hatch and continuing throughout the remainder of the larval period (Fig. 2). Otolith growth trajectories of the Fall 1 cohort were more complex. Beginning around Days 5 to 15 , otolith growth rates were faster for groups with shorter PLDs than those with longer PLDs, but this pattern then reversed during the middle $15 \mathrm{~d}$ of the period. Between Days 35 and 45, the initial pattern of higher growth for short PLD groups reemerged (Fig. 2). All Fall 1 group comparisons exhibited this pattern, except for Groups 50 to $54 \mathrm{~d}$ versus 55 to $59 \mathrm{~d}$, in which the shorter PLD group had initially slower otolith growth until $\sim 25 \mathrm{~d}$ prior to settlement, when it exhibited faster otolith growth (canonical loadings).

Hindcast otolith growth rates among groups with differing PLDs exhibited a clear, consistent trend (Fig. 3). In general, groups with shorter PLDs grew significantly faster prior to settlement than groups with longer PLDs, and this difference was significant for all but 3 comparisons (repeated-measures MANOVA: Table 1). The dip in growth rates evident in the progressive trajectories in the Fall 1 cohort (Fig. 2) occurred at the same time for all fish in the cohort ( 14 to $18 \mathrm{~d}$ pre-settlement: Fig. 3). In addition, this period of reduced otolith growth had the same duration ( 15 d), and was of the same magnitude (lowest otolith growth was $\sim 3.5 \mathrm{~mm} \mathrm{~d}^{-1}$ ) for all PLD groups. Furthermore, although progressive larval trajectories were not significantly different among PLD groups in the Spring cohort, hindcast trajectories were (Table 1). Fish with shorter PLDs were growing faster at the time of settlement.

We examined otolith length-at-age plots to see how differences in otolith growth related to length differences throughout the larval period. Similar to results for progressive larval growth, fish with shorter PLDs exhibited larger length-at-age. These trends were significant for all comparisons in both fall cohorts, but were not significant for any group comparisons in the spring cohort (repeated-measures MANOVA: Fig. 2; Table 1).

Settlement and metamorphosis

In all cohorts, average otolith length at settlement was smaller for groups with shorter larval durations ( $T^{\prime}$ method: Tables 1 \& 2). These otolith measurements were supported by somatic length measurements of fishes from both fall cohorts. Fish settling after shorter larval durations were smaller (smaller standard length and dry weight) at emergence (Table 3). In the metamorphic period, there was a consistent trend toward a narrower otolith metamorphic band in groups with longer PLDs (Table 2); however, this trend was signifi- 

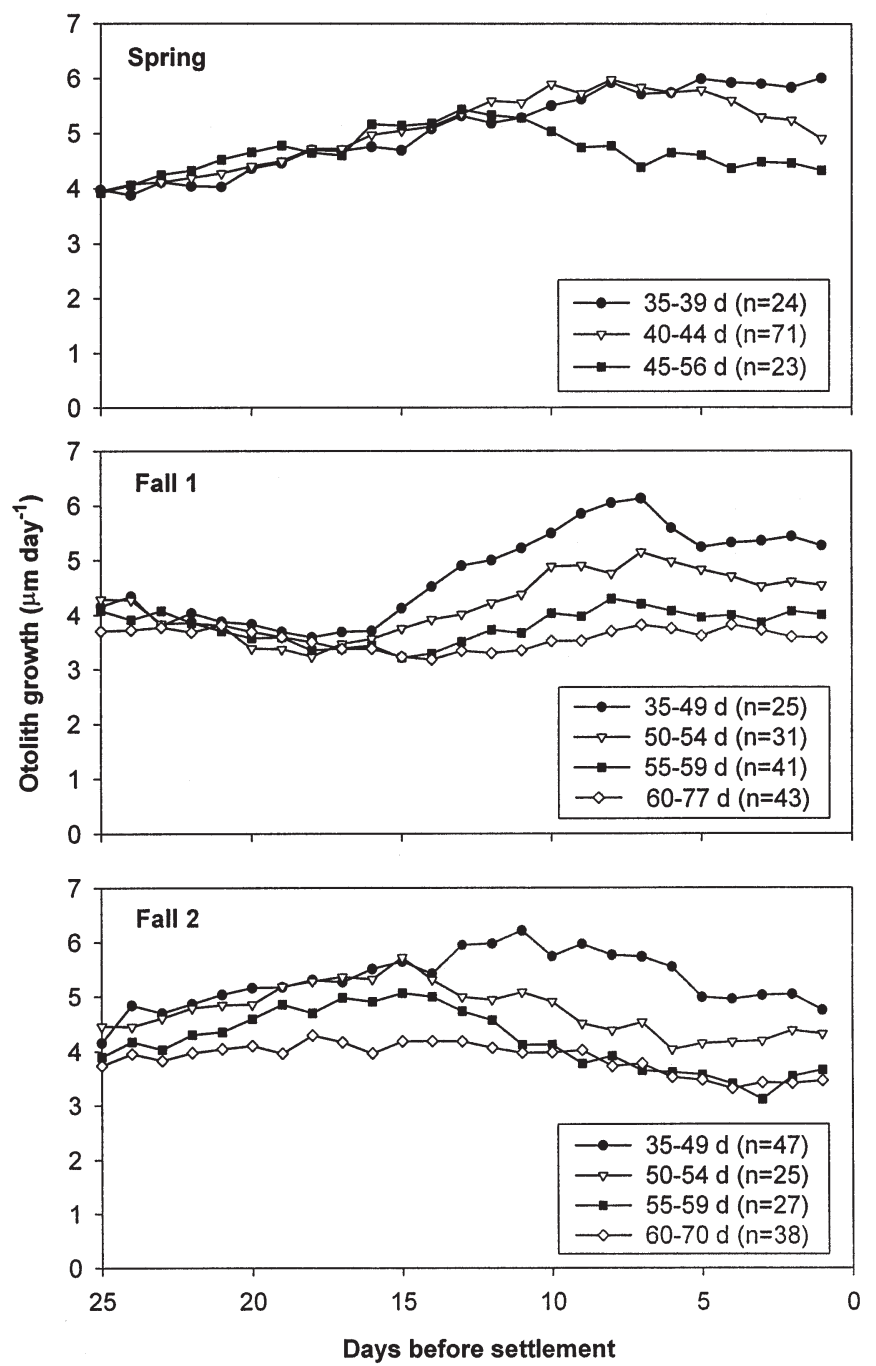

Fig. 3. Thalassoma bifasciatum. Mean hindcast larval otolith growth-rate trajectories for 3 seasonal cohorts. Within each cohort, fish were divided into groups based on PLD. Note that days are plotted prior to settlement (i.e. $5=5 \mathrm{~d}$ prior to settlement)

cant in only 4 PLD comparisons in the Fall 2 cohort $\left(T^{\prime}\right.$ method: Table 1).

Juveniles

In all 3 cohorts there was no significant difference in juvenile otolith growth rates between groups with short and long larval durations (Fig. 4; repeated-measures MANOVA, $p>0.05$ ). Despite this, the trend in juvenile otolith length-at-age was that fish with longer larval durations had larger otoliths at age in the early juvenile period (significant for both fall cohorts but not the spring cohort; repeated-measures MANOVA; Fig. 4).
Table 2. Thalassoma bifasciatum. Otolith length-at-settlement and width of otolith metamorphic band for 3 cohorts with different pelagic larval duration

\begin{tabular}{|lcrrrrrrr|}
\hline \multirow{2}{*}{$\begin{array}{l}\text { Cohort, } \\
\text { PLD }\end{array}$} & (n) & \multicolumn{3}{c}{$\begin{array}{c}\text { Otolith length-at- } \\
\text { settlement }(\mu \mathrm{m})\end{array}$} & \multicolumn{3}{c|}{$\begin{array}{c}\text { Otolith metamorphic } \\
\text { band width }(\mu \mathrm{m})\end{array}$} \\
group (d) & & Mean & SD & Range & Mean & SD & Range \\
\hline Spring & & & & & & & \\
$35-39$ & $(24)$ & 169.0 & 8.7 & $150-186$ & 29.5 & 3.4 & $23-36$ \\
$40-44$ & $(71)$ & 181.0 & 7.8 & $163-197$ & 28.8 & 4.8 & $15-42$ \\
$45-56$ & $(23)$ & 188.5 & 11.9 & $163-214$ & 27.9 & 4.0 & $21-37$ \\
Fall 1 & & & & & & & \\
$35-49$ & $(25)$ & 192.0 & 17.2 & $157-228$ & 24.7 & 4.9 & $15-34$ \\
$50-54$ & $(31)$ & 202.7 & 12.1 & $175-228$ & 24.6 & 4.9 & $15-36$ \\
$55-59$ & $(41)$ & 216.1 & 10.4 & $189-239$ & 23.4 & 5.5 & $12-35$ \\
$60-70$ & $(43)$ & 228.9 & 14.3 & $211-275$ & 23.4 & 4.7 & $13-35$ \\
Fall 2 & & & & & & & \\
$35-44$ & $(22)$ & 185.2 & 11.7 & $167-204$ & 22.0 & 3.3 & $16-30$ \\
$45-54$ & $(40)$ & 212.5 & 10.5 & $186-236$ & 22.7 & 4.2 & $13-32$ \\
$55-59$ & $(27)$ & 219.4 & 11.6 & $196-244$ & 19.7 & 4.2 & $13-30$ \\
$60-70$ & $(38)$ & 230.9 & 13.0 & $209-268$ & 18.7 & 4.2 & $9-27$ \\
& & & & & & & \\
\hline
\end{tabular}

Table 3. Mean standard length (SL) and dry weight (DW) for $<1 \mathrm{~d}$ old recruits of Thalassoma bifasciatum. Comparisons were made between groups of short and long pelagic larval duration. ANOVA results: ${ }^{*},{ }^{* *}$ significant at $\mathrm{p}<0.001$ and $\mathrm{p}<0.01$, respectively

\begin{tabular}{|lrrrrr|}
\hline $\begin{array}{l}\text { Cohort, PLD } \\
\text { group (d) }\end{array}$ & (n) & \multicolumn{2}{c}{ SL (mm) } & \multicolumn{2}{c|}{ DW (mg) } \\
Mean & ANOVA & Mean ANOVA \\
\hline Fall 1 & & & & & \\
$34-59$ & $(13)$ & 11.5 & $* *$ & 4.7 & $*$ \\
$60-69$ & $(7)$ & 12.2 & & 5.5 & \\
Fall 2 & & & & & $*$ \\
$34-55$ & $(9)$ & 11.21 & $*$ & 4.7 & $*$ \\
$58-69$ & $(12)$ & 11.7 & & 5.5 & \\
\hline
\end{tabular}

\section{Among-cohort comparisons}

Mean PLD for each cohort did not vary significantly between the 2 fall cohorts; however, the spring cohort spent a significantly shorter period in the plankton than either fall cohort ( $T^{\prime}$ method, $\mathrm{p}<0.05$; Fig. 1). There is no consistent pattern (shape) in the mean progressive growth trajectories. The Fall 1 cohort had a sinusoidal growth trajectory, while the Fall 2 and Spring cohorts had a more sigmoidal (domed) shape (Fig. 5). Progressive larval growth trajectories for all 3 cohorts were significantly different from each other (repeatedmeasures MANOVA, $\mathrm{p}<0.001$ ). Canonical loadings indicated that the main difference in progressive otolith growth occurred between Days 25 and 40, with the Spring cohort exhibiting the highest growth and the Fall 1 cohort exhibiting the slowest growth during this period. Larval otolith length-at-age, following 

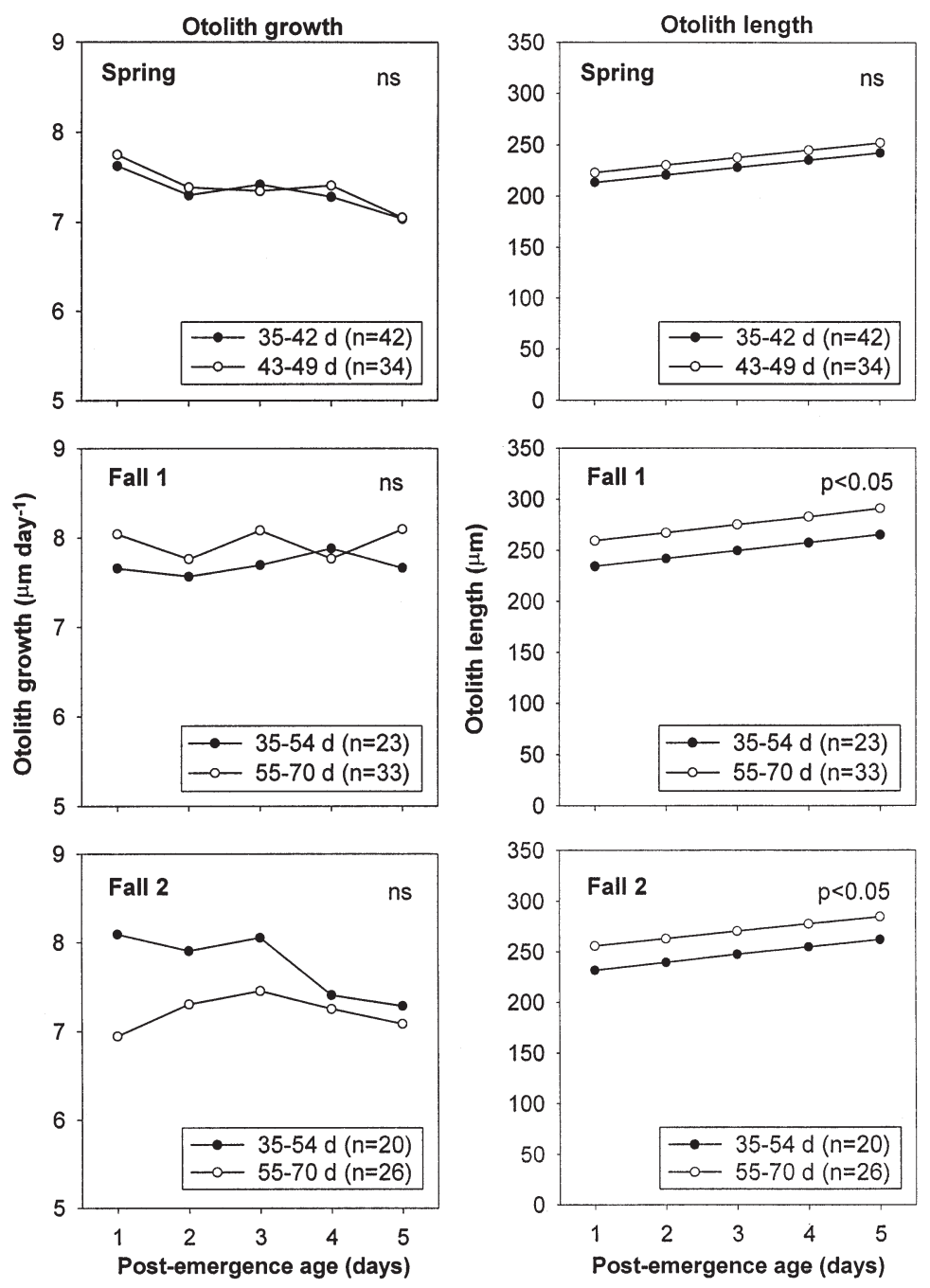

Fig. 4. Thalassoma bifasciatum. Mean juvenile otolith growth rate (left panels), and juvenile otolith length-at-age (right panels) for 3 seasonal cohorts. Each plot is based on 2 groups of shorter and longer PLD within each cohort. Resultsare repeated-measures MANOVA. ns = non-significant at $\mathrm{p}>0.05$

\section{DISCUSSION}

\section{Larval growth}

The variability of early life-history traits (e.g. pelagic larval duration, growth rates, and size-at-age) for Thalassoma bifasciatum within the larval phase reveal that this is a dynamic period. Within each cohort, $T$. bifasciatum with shorter larval durations had faster otolith growth than individuals with relatively longer larval durations. While laboratory experiments may be necessary to disentangle endogenous and exogenous controls of growth (Conover \& Schultz 1997), analysis of available factors can shed light on the most likely proximate causes. Among potential exogenous factors, temperature is unlikely to have contributed significantly to the observed differences in growth rates, as water temperatures were relatively similar during the larval period of each cohort: Spring, 27.0 to $27.4^{\circ} \mathrm{C}$; Fall 1, 27.3 to $28.1^{\circ} \mathrm{C}$; Fall 2, 27.4 to $28.4^{\circ} \mathrm{C}$ (data from moored CT sensors at $10 \mathrm{~m}$ depth, $2 \mathrm{~km}$ offshore of the west coast of Barbados; P. S. Kelly \& K. M. M. Lwiza unpubl. data). Furthermore, contrary to what might be expected in colder temperatures, the spring cohort exhibited the fastest overall growth.

Of greater potential influence is variation in food availability. Previous studies have demonstrated increased otolith growth for larvae in areas of elevated food abundance (e.g. Hovenkamp \& Witte 1991, Molony \& Sheaves 1998). In addition, otolith growth of populations of juvenile Thalassoma bifasciatum was shown to increase when food

trends in growth, was also significantly different among all cohorts (repeated measures MANOVA, p $<0.001$; Fig. 5). Similar to progressive trajectories, hindcast larval growth trajectories differed significantly among cohorts (repeated-measures MANOVA, p < 0.001; Fig. 5). The Spring cohort exhibited the fastest growth for $15 \mathrm{~d}$ prior to settlement and the Fall 1 cohort had the slowest growth as is evident in the a dip in growth between 10 and $25 \mathrm{~d}$ before settlement (canonical loadings; Fig. 5).

Daily juvenile otolith growth for the initial $7 \mathrm{~d}$ after emergence did not differ significantly among the 3 seasonal cohorts (repeated-measures MANOVA, p > 0.05; Fig. 6). Juvenile otolith length-at-age, however, was smaller for the spring cohort as a result of smaller otolith sizes at settlement (repeated-measures MANOVA, p < 0.01; Fig. 6). levels were supplemented (Victor 1982). We suggest that the observed differences in otolith growth rates among individual $T$. bifasciatum larvae are due to variability in food abundance. Food concentrations may vary on the scale of individuals or patches of individuals as well as on the order of entire cohorts, and may result from 2 non-exclusive processes. A gradient of decreasing food concentrations may extend offshore of Barbados, whereby nearshore coastal waters are enriched relative to offshore waters (island mass effect: Sander 1981, Hernandez-Leon 1991). This onshoreoffshore gradient would result in nearshore larvae with faster growth rates and offshore larvae with relatively depressed growth rates due to lower food concentrations. Alternatively, through hydrodynamic control, the distribution of food may be patchy throughout the 

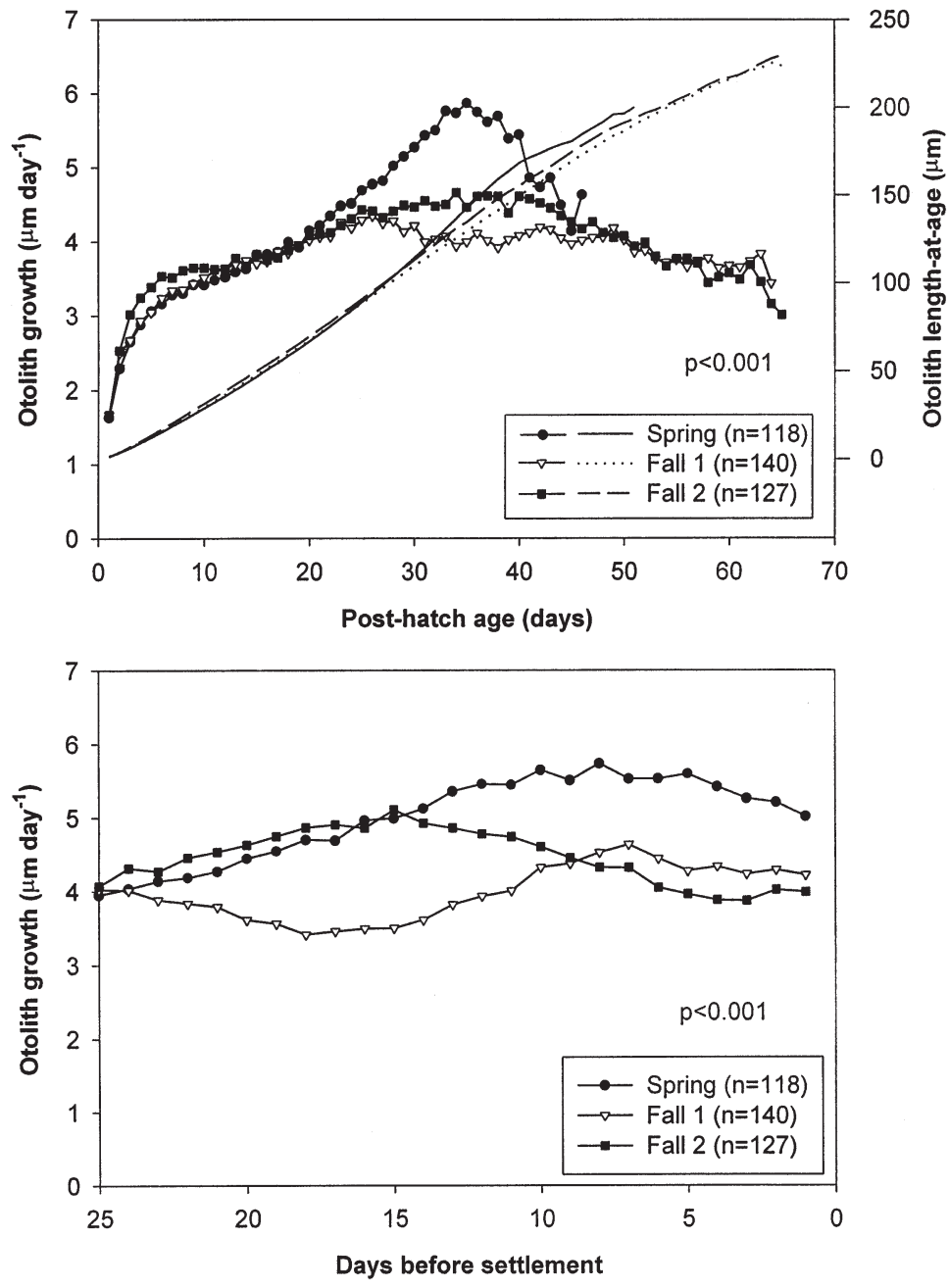

Fig. 5. Thalassoma bifasciatum. Upper panel is mean progressive larval otolith growth-rate trajectories (lines with symbols) and larval otolith length-at-age (continuous, dashed, and dotted lines) for 3 seasonal cohorts. Lower panel is mean hindcast larval otolith growth-rate trajectories. All among-cohort comparisons of trajectories were significantly different at $\mathrm{p}<0.001$; repeated-measures MANOVA

nearshore and offshore environment (e.g. concentrated at convergence zones: Kingsford 1990, Boehlert \& Mundy 1993). As a result, relatively faster growth may occur in larvae that spend proportionally more time in food patches. The stability of these features, food concentration, as well as the proportion of time larvae are retained within them probably vary, producing a range of larval growth rates.

\section{Variable growth rates versus delayed metamorphosis}

The variability in larval durations observed for Thalassoma bifasciatum in this study is similar to that reported in other studies (Table 4). Extreme differences in PLD may reflect the capacity of individuals to delay settlement and metamorphosis until certain criteria are met. In such cases, larvae typically grow at similar rates until they are competent to settle, at which time the majority settle and undergo metamorphosis. A minority that are unable to settle at that time experience reduced growth until settlement is possible (e.g. Victor 1986, Cowen 1991, Jenkins \& May 1994). For example, Victor (1986) demonstrated that $T$. bifasciatum larvae with relatively long larval durations ( $\sim 75 \mathrm{~d})$ recruiting to Panama had a sharp decline in otolith growth rates prior to settlement. Recently, Robertson et al. (1999) observed that $T$. bifasciatum recruiting to Panama varied in PLD, depending on the period of the lunar cycle in which they were spawned, such that settlement is concentrated around the new moon. They suggested that variable larval duration provides greater flexibility in synchronizing settlement, as previously proposed for a tropical goby (Gnatholepis thompsoni: Sponaugle \& Cowen 1994).

The results of the current study suggest that the observed variation in PLD is not simply the result of delayed metamorphosis. Although the ranges of PLDs exhibited by Thalassoma bifasciatum in the current study are typical (see Table 4), none of the individuals examined exhibited a characteristic 'delayer' otolith growth trajectory (sensu Victor 1986). Larval duration appears to be the result of growth rates that vary from the time of hatching.

The relative importance of classic delayers to recruitment dynamics likely varies with geographic and hydrographic settings. The paucity of delayers recruiting to Barbados suggests that periodic physical mechanisms (e.g. tidally mediated flows and features: Kingsford 1990, Sponaugle \& Cowen 1997, Leichter et al. 1998), retention mechanisms (e.g. Cowen \& Castro 1994), or perhaps the swimming ability of late-stage larvae (Leis et al. 1996, Stobutzki \& Bellwood 1997) insure successful return to the reef. Most workers who have found delayed metamorphosis to be common have collected fish far from their spawning grounds (Cowen 1991, Jenkins \& May 1994, Fowler \& Short 1996, but see Victor 1986). However, Barbados is upstream from other sources of larvae and thus recruits are likely to be spawned locally and retained within the vicinity of the island until set- 

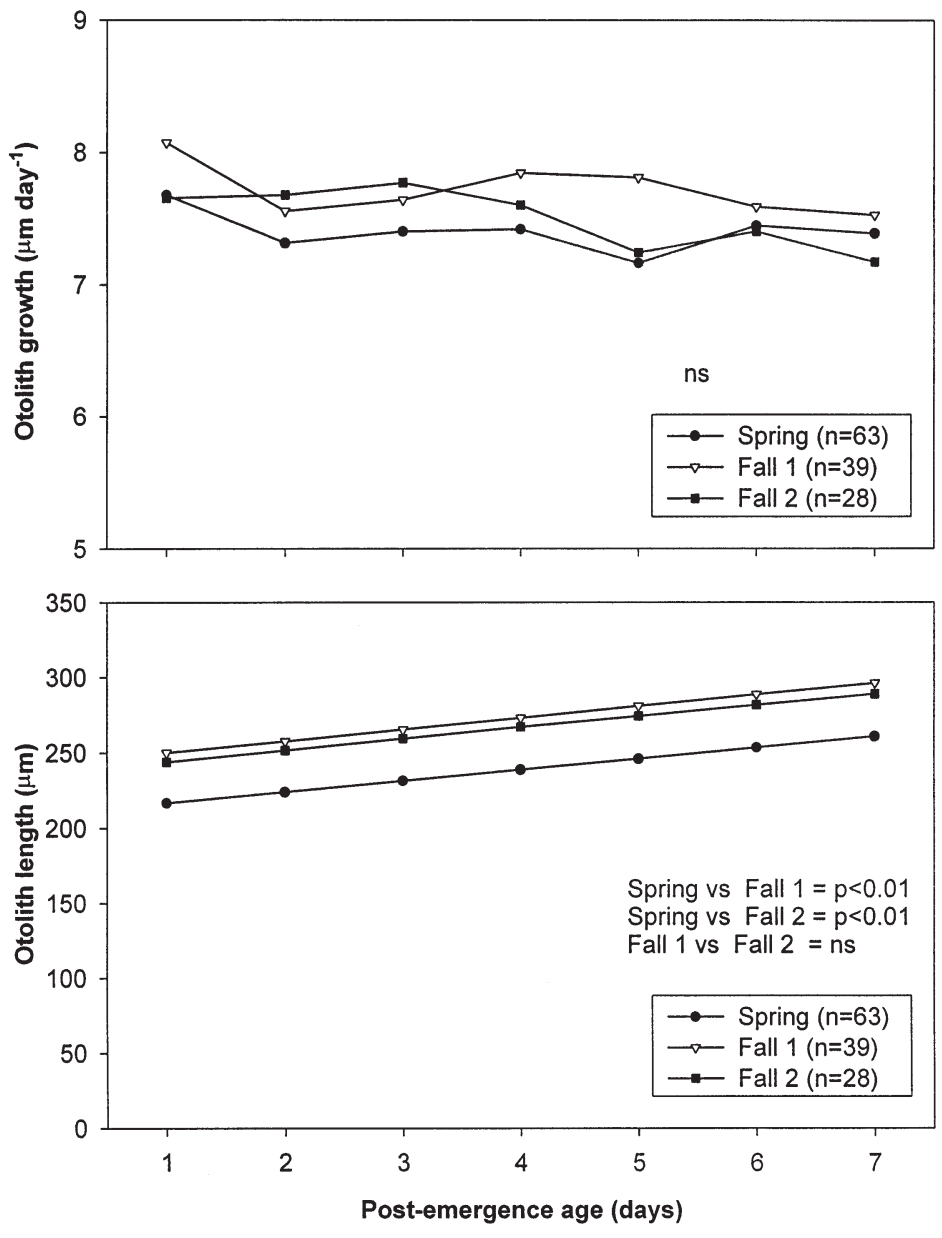

Fig. 6. Thalassoma bifasciatum. Mean juvenile otolith growth rate (upper panel) and juvenile otolith length-at-age (lower panel) for the 3 seasonal cohorts. Results are repeated-measures MANOVA for amongcohort comparisons. $n s=$ non-significant at $\mathrm{p}>0.05$

tlement (Cowen \& Castro 1994, Sponaugle \& Cowen 1996, Cowen et al. 2000), or transported downstream and lost from the system.

\section{Competency}

The exact determination of when competency to settle is reached may be difficult to judge, as no 1 factor has been conclusively linked to its attainment. Invertebrates have been shown to reach competency according to behavior, size, morphological characteristics, or a minimum age (reviewed in Pechenik 1990). Similarly, competence in demersal fishes has also been defined based on median age, minimum weight, length, or according to a sharp reduction in otolith growth rates (reviewed in McCormick 1999). Implicit in these definitions is that competency is also related to developmental state. Recent physiological work has shown that sensory development (eye, lateral line, nares) of Thalassoma bifasciatum at settlement is relatively invariant (Lara 1999). Thus, $T$. bifasciatum settles at a range of ages and sizes, yet at a similar developmental state. To account for this, development must be decoupled from growth rates (e.g. Gadomski \& Caddell 1991, McCormick 1993), or arrested at a certain point. No doubt several criteria must be met for settlement to occur, but we suggest that final competency is linked not only to developmental level but also to condition.

Energy is lost, not gained, during metamorphosis (e.g. Balon 1985); therefore, only fishes with sufficiently high energy stores will successfully complete this energetically costly process. This is particularly critical for Thalassoma bifasciatum, which undergoes a protracted period of metamorphosis during which no feeding occurs (Searcy \& Sponaugle in press). The need for nutritional reserves to undergo metamorphosis has been shown in a variety of marine invertebrates (e.g. Pechenik 1990, Pechenik et al. 1993). An increase in fat content just prior to metamorphosis and rapid depletion of lipids during metamorphosis has also been confirmed for multiple fish species (Potter et al. 1978, Pfeiler \& Luna 1984, Nursall 1989). In addition, studies of temperate species have shown that critical developmental stages such as sexual maturation is suppressed until a minimum condition level is met (Rowe et al. 1990, Montgomery \& Galzin 1993), and this may also be true of metamorphosis.

In the current study, a minimum condition level for settlement could explain the observed difference in length at settlement between slower and faster growers. Previous work on a variety of species has shown that larvae with faster otolith growth have a higher condition than larvae with slower otolith growth (reviewed by Suthers 1998). Therefore, slow-growing larvae may need to remain in the plankton longer (and thus attain larger sizes) to obtain sufficient energy stores for metamorphosis.

Although we have no direct measure of condition at settlement, we believe that condition is reflected in certain otolith characteristics. Molony \& Sheaves (1998) suggested that the rate of the otolith growthresponse to food deprivation may be influenced by lipid concentration, where decreased otolith growth is most likely to occur in fishes with low energy stores. Metamorphosis in Thalassoma bifasciatum is generally considered a period of food deprivation (starvation 
Table 4. Thalassoma bifasciatum. Summary of published values of pelagic larval duration (PLD; in d). CV = coefficient of variation; $_{\text {? }}=$ published value not given; values in parentheses are interpreted from authors' published data (Caselle 1997, Fig. 2; Robertson et al. 1999, Fig. 13); Masterson et al. (1997) report PLD range for all 3 cohorts collected and PLD estimate is obtained from lapilli rather than sagittae (sagittae used in other studies listed). Lapillae readings may (Victor 1982, Robertson et al. 1999) or may not (Schultz \& Cowen 1991; 3 d difference) be similar to sagittae readings

\begin{tabular}{|c|c|c|c|c|c|c|}
\hline \multirow{2}{*}{$\begin{array}{l}\text { Location, } \\
\text { season }\end{array}$} & \multirow[t]{2}{*}{ Year } & \multirow[t]{2}{*}{ (n) } & \multicolumn{2}{|c|}{ PLD (d) } & \multirow[t]{2}{*}{$\mathrm{CV}$} & \multirow[t]{2}{*}{ Source } \\
\hline & & & Mean & Range & & \\
\hline \multicolumn{7}{|l|}{ Barbados } \\
\hline Spring & 1997 & $(140)$ & 42.4 & $37-58$ & 7.4 & Current study \\
\hline Fall & 1997 & (127) & 56.8 & $34-79$ & 12.2 & Current study \\
\hline Fall & 1997 & (118) & 55.3 & $36-78$ & 16.3 & Current study \\
\hline Spring & 1992 & $(37)$ & 49.2 & $41-66$ & 10.4 & Sponaugle \& Cowen (1997) \\
\hline Spring & 1991 & (26) & 53.2 & $41-94$ & 25.2 & Sponaugle \& Cowen (1997) \\
\hline Spring & 1990 & $(32)$ & 49.0 & $38-64$ & 12.7 & Sponaugle \& Cowen (1997) \\
\hline \multicolumn{7}{|l|}{ St. Croix } \\
\hline Summer & 1993 & $(130)$ & 37 & & 16.2 & Masterson et al. (1997) \\
\hline Summer & 1992 & $(157)$ & 40 & $29-63$ & 15 & Masterson et al. (1997) \\
\hline Summer & 1991 & $(88)$ & 41 & & 12.2 & Masterson et al. (1997) \\
\hline Summer & 1992 & $(286)$ & 45.8 & $35-61$ & $(9.9)$ & Caselle (1997) \\
\hline Summer & 1992 & $(20)$ & 51.4 & $41-74$ & 15.5 & Sponaugle (1994) \\
\hline Spring & 1991 & $(22)$ & 40.2 & $35-50$ & 8.3 & Sponaugle (1994) \\
\hline \multicolumn{7}{|l|}{ St. Lucia } \\
\hline Spring & 1992 & (31) & 45.6 & $37-63$ & 9.8 & Sponaugle (1994) \\
\hline Spring & 1991 & (28) & 41 & $34-53$ & 10.7 & Sponaugle (1994) \\
\hline \multicolumn{7}{|l|}{ Panama } \\
\hline & 1985-1987 & $(776)$ & $(44.7)$ & $29-67$ & $(12.6)$ & Robertson et al. (1999) \\
\hline & $1981-1983$ & (1172) & 49.3 & $38-78$ & 11.2 & Victor (1986) \\
\hline \multicolumn{7}{|l|}{ Bermuda } \\
\hline Fall & 1991 & $(47)$ & 55 & ? & 18.9 & Schultz \& Cowen (1994) \\
\hline
\end{tabular}

event) during which somatic growth is negligible. We propose that otolith accretion in the metamorphic band is likely to reflect condition at settlement, such that individuals with wider metamorphic bands (more rapid accretion of material) have a higher condition at settlement (Searcy \& Sponaugle in press). Furthermore, for both $T$. bifasciatum and another wrasse, Halichoeres bivittatus, individuals with wider metamorphic bands preferentially survived the early juvenile period (Searcy \& Sponaugle in press), indicating that traits expressed during metamorphosis (i.e. condition) are critical in determining early juvenile mortality.

While a minimum condition level may be necessary for Thalassoma bifasciatum larvae to complete metamorphosis, a range in condition probably exists above this minimum that is independent of larval duration. The 3 cohorts examined exhibited an overall tendency for fish with shorter PLDs to have wider metamorphic bands; however, variation within each of these PLD groups encompassed the entire range observed for the cohort. Furthermore, Searcy \& Sponaugle (in press) demonstrated that selective mortality on the width of the metamorphic band for $T$. bifasciatum was independent of larval duration. These results suggest that the width of the metamorphic band, or condition at settlement, is largely independent of age or size, as has been con- cluded for different species in several previous studies (McCormick \& Molony 1993, 1995, Kerrigan 1996).

\section{Influence of larval traits on juveniles}

Variability in early life-history traits at settlement did not appear to affect juvenile growth rates; consequently, size differences at settlement were propagated (and did not diverge or converge significantly) $5 \mathrm{~d}$ into the juvenile stage. Regardless of larval growth history, seasonal cohorts as well as all intra-cohort PLD groups exhibited similar juvenile growth rates. In a laboratory study of winter flounder Pseudopleuronectes americanus, Chambers et al. (1988) found that size advantages gained from the larval stage were perpetuated into the juvenile period. In contrast, Bertram et al. $(1993,1997)$ demonstrated that size differences at settlement for the same species were compensated for by juvenile growth rates. As adult Thalassoma bifasciatum exist in large conspecific groups, if size differences at settlement are maintained with age, then they may confer advantages in competing for resources such as food and mates (e.g. McCormick \& Kerrigan 1996). Further, the fact that size differences from the larval phase were maintained during the first $5 \mathrm{~d}$ of the 
juvenile period is interesting because post-settlement mortality rates (e.g. Victor 1986, Hixon 1991, Caselle 1999) and selective mortality are highest during the first few days on the reef (Searcy \& Sponaugle in press). Relatively constant juvenile growth rates among individuals with different pelagic (larval) histories indicate that at least initially the reef environment (with regard to food availability for young fishes) is stable, or that selective pressures favor less variable growth regardless of what occurs in the pelagic environment.

\section{Among-cohort variation in early life-history traits}

The difference in the range of PLD between the fall and spring cohorts in the current study may have been due to cohort specific processes rather than seasonal features. Previous spring cohorts collected at Barbados in 1990, 1991, and 1992 (Table 4: Sponaugle \& Cowen 1997 data) had mean PLDs that more nearly resembled the fall cohorts in the current study. The high larval growth rates exhibited by the spring cohort may have been caused by relatively high planktivorous food concentrations, or if slower growers are dispersed farther offshore, then perhaps the loss of these individuals from the recruiting cohort (breakdown in offshoreretention system).

The role of episodic events in influencing cohort characteristics is also suggested by contrasting larval growth trajectories. The large dip in growth rates midway through the larval period of the Fall 1 cohort occurred during the presence of a low-salinity eddy that passed Barbados just prior to the observed period of reduced growth (Kelly et al. 2000). We suggest that this eddy contained lower densities of prey organisms, which reduced the feeding success of larval fishes. Thus, on a small temporal scale, hydrodynamic features may significantly influence larval traits.

Oceanographic features may also help explain geographical differences in larval characteristics such as PLD (see Table 4). Although there is much spatial and temporal overlap in Thalassoma bifasciatum PLD, general trends between the longer time series from Barbados and St. Croix tentatively suggest that the 2 sites have distinctly different hydrodynamic regimes from each other ( $T$. bifasciatum from St. Croix tend to have a shorter PLD). Physical transport processes (i.e. shorter period of a recirculating mechanism) as well as relatively constant local environmental conditions influencing growth (food or temperature) may be the basis for the observed shorter PLD in St. Croix. Overall, the fluctuations in PLD within each of the time series highlight the role of episodic events in influencing characteristics of individual cohorts, and caution against comparisons based on collections of only a few cohorts. Clearly, conclusions as to a genetic basis for the observed differences cannot be made unless the pelagic environment is first taken into consideration.

The variable nature of growth rates and thus the PLD of fishes such as Thalassoma bifasciatum is probably a response to a range of planktonic food availability. For pelagic spawners with moderately long PLD (such as $T$. bifasciatum), larval growth plasticity would be advantageous since the odds of encountering low food conditions (by being transported offshore or encountering low food patches) are high. On the other hand, for certain species with relatively short, invariant larval durations (e.g. damselfish: Wellington \& Victor 1989) fast growth may be coupled to a strategy of remaining in high food areas and/or maximizing retention near the adult habitat (e.g. Leis 1991, Cowen \& Castro 1994). If these larvae are then transported out of nearshore or food-rich areas, or if productivity drops, their high physiological demands may be compromised, resulting in greatly reduced survival. In short, particular taxa (such as T. bifasciatum) appear to have the physiological ability to tolerate low growth rates while others do not. This dichotomy is evident in recent work that has shown that new recruits of another wrasse, Halichoeres bivittatus, with a relatively short and invariant larval duration (mean PLD $22 \mathrm{~d} \pm 1 \mathrm{SD}$ ) exhibit strong selection for faster larval growth, whereas $T$. bifasciatum does not (Searcy \& Sponaugle in press). The fact that $T$. bifasciatum larvae are able to recruit successfully over a wide range of larval durations (within each cohort) as well as atypical growth patterns (i.e. Fall 1 cohort) stresses the potential ecological advantage and evolutionary importance of plastic growth and flexible larval durations.

A further implication of flexible larval growth schedules is the degree to which distant populations are ecologically connected. While physical diffusion and natural mortality combine to make long-distant transport unlikely (Cowen et al. 2000), the ability of larvae to survive long periods of low growth (i.e. in oligotrophic open-ocean waters) will clearly impact transport success. Significant population replenishment from distant locations would be more likely for species with larvae that are able to tolerate slow growth for extended periods of time.

Acknowledgements. The comments of R. Cowen substantially improved earlier versions of this manuscript. Additionally, we thank D. Conover, S. Dorsey, C. Paris, J. Purcell, and N. Reyns for critical discussions and comments of various drafts of this manuscript. Fieldwork was accomplished with the help of R. Cowen, S. Dorsey, and N. Reyns. The Bellairs Research Institute of McGill University made field facilities available. This research was supported by National Science Foundation Grant No. OCE-9521104 to R. K. Cowen, K. Lwiza, and E. T. Schultz. This represents contribution number 1191 from the Marine Sciences Research Center. 


\section{LITERATURE CITED}

Balon EK (1985) The theory of saltatory ontogeny and life history models revisited. In: Balon EK (ed) Early life histories of fishes. Dr W Junk Publishers, Boston, p 13-30

Bell KNI, Pepin P, Brown JA (1995) Seasonal, inverse cycling of length and age-at-recruitment in the diadromous gobies Sicydium punctatum and Sicydium antillarum in Dominica, West Indies. Can J Fish Aquat Sci 52: 1535-1545

Bertram DF (1996) Size-dependent predation risk in larval fishes: mechanistic inferences and levels of analysis. Fish Bull US 94:371-373

Bertram DF, Leggett WC (1994) Predation risk during the early life history periods of fishes: separating the effects of size and age. Mar Ecol Prog Ser 109:105-114

Bertram DF, Chambers RC, Leggett WC (1993) Negative correlations between larval and juvenile growth rates in winter flounder: implications of compensatory growth for variation in size-at-age. Fish Bull US 96:209-215

Bertram DF, Miller TJ, Leggett WC (1997) Individual variation in growth and development during the early life stages of winter flounder, Pleuronectes americanus. Mar Ecol Prog Ser 95:1-10

Boehlert GW, Mundy BC (1993) Ichthyoplankton assemblages at seamounts and oceanic islands. Bull Mar Sci 53:336-361

Caselle JE (1997) Small scale spatial variation in early life history characteristics of a coral reef fish: implications for dispersal hypotheses. In: Lessios HA, Macintyre I (eds) Proc 8th Int Coral Reef Symp 2. Smithsonian Tropical Research Institute, Panamá, p 1161-1166

Caselle JE (1999) Early post-settlement mortality in a coral reef fish and its effect on local population size. Ecol Monogr 69(2):177-194

Chambers RC (1997) Environmental influences on egg and propagule sizes in marine fishes. In: Chambers RC, Trippel E (eds) Early life history and recruitment in fish populations. Chapman \& Hall, New York, p 63-95

Chambers RC, Leggett WC (1987) Size and age at metamorphosis in marine fishes: an analysis of laboratory-reared winter flounder (Pseudopleuronectes americanus) with a review of variation in other species. Can J Fish Aquat Sci 44:1936-1947

Chambers RC, Leggett WC (1992) Possible causes and consequences of variation in age and size at metamorphosis in flatfishes (Pleuronectiformes): an analysis at the individual, population, and species levels. Neth J Sea Res 29 $(1-3): 7-24$

Chambers RC, Miller TJ (1995) Evaluating fish growth by means of otolith increment analysis: special properties of individual-level longitudinal data. In: Secor DH, Dean JM, Campana SE (eds) Recent developments in fish otolith research. University of South Carolina Press, Columbia, p 155-175

Chambers RC, Leggett WC, Brown JA (1988) Variation in and among early life history traits of laboratory-reared winter flounder Pseudopleuronectes americanus. Mar Ecol Prog Ser 47:1-15

Conover DO, Schultz ET (1997) Natural selection and the evolution of growth rate in the early life history: what are the trade-offs? In: Chambers RC, Trippel E (eds) Early life history and recruitment in fish populations. Chapman \& Hall, New York, p 305-332

Cowen RK (1991) Variation in the planktonic larval duration of the temperate wrasse Semicossyphus pulcher. Mar Ecol Prog Ser 69:9-15
Cowen RK, Castro LR (1994) Relation of coral reef fish larval distributions to island scale circulation around Barbados, West Indies. Bull Mar Sci 54(1):228-244

Cowen RK, Sponaugle S (1997) Relationships between early life history traits and recruitment among coral reef fishes. In: Chambers RC, Trippel E (eds) Early life history and recruitment in fish populations. Chapman \& Hall, New York, p 261-293

Cowen RK, Lwiza KMM, Sponaugle S, Paris C, Olson D (2000) Connectivity of marine populations: open or closed? Science 287:857-859

Fitzhugh GR, Nixon SW, Ahrenholz DW, Rice JA (1997) Temperature effects on otolith microstructure and birth month estimation from otolith increment patterns in the Atlantic menhaden. Trans Am Fish Soc 126:579-593

Forrester GE (1990) Factors influencing the juvenile demography of a coral reef fish population. Ecology 71: 1666-1681

Fowler AJ (1989) Description, interpretation and use of the microstructure of otoliths from juvenile butterflyfishes (family Chaetodontidae). Mar Biol 102:167-181

Fowler AJ, Short DA (1996) Temporal variation in the early life-history characteristics of the King George whiting (Sillaginodes punctata) from analysis of otolith microstructure. Mar Freshw Res 47:809-818

Gadomski DM, Caddell SM (1991) Effects of temperature on early-life-history stages of California halibut Paralichthys californicus. Fish Bull US 89:567-576

Hare JA, Cowen RK (1995) The effect of age, growth rate and ontogeny on the relationship between otolith and somatic size in bluefish, Pomatomus saltatrix, and the implications for the backcalculation of size in the early life stages of fishes. Can J Fish Aquat Sci 52:1909-1922

Hernandez-Leon S (1991) Accumulation of meso-zooplankton in a wake area as a causative mechanism of the 'island mass effect'. Mar Biol 109:141-147

Hixon MA (1991) Predation as a process structuring coral reef fish communities. In: Sale PF (ed) The ecology of fishes on coral reefs. Academic Press, San Diego, p 475-507

Hovenkamp F (1990) Growth differences in larval plaice Pleuronectes platessa in the Southern Bight of the North Sea as indicated by otolith increments and RNA/DNA ratios. Mar Ecol Prog Ser 58:205-215

Hovenkamp F, Witte JIJ (1991) Growth, otolith growth and RNA/DNA ratios of larval plaice Pleuronectes platessa in the North Sea 1989-1989. Mar Ecol Prog Ser 70:105-116

Jenkins GP, May HMA (1994) Variation in settlement and larval duration of King George Whiting, Sillaginodes punctata (Sillaginidae), in Swan Bay, Victoria, Australia. Bull Mar Sci 54(1):281-296

Kelly PS, Lwiza KMM, Cowen RK, Goni G (2000) Low-salinity pools at Barbados, West Indies: their origin, frequency and variability. J Geophys Res 105:19699-19708

Kerrigan BA (1996) Temporal patterns in size and condition at settlement in two tropical reef fishes (Pomacentridae: Pomacentrus amboinensis and P. nagasakiensis). Mar Ecol Prog Ser 135:27-41

Kingsford MJ (1990) Linear oceanographic features: a focus for research on recruitment processes. Aust J Mar Ecol 15: 391-401

Lara M (1999) A comparative study of sensory development in settlement-stage larvae of Caribbean labrids and scarids with implications for ecomorphology and life history strategies. Dissertation. College of William and Mary, Williamsburg, VA

Leichter JJ, Shellenbarger G, Genovese SJ, Wing SR (1998) Breaking internal waves on a Florida (USA) coral reef: a 
plankton pump at work? Mar Ecol Prog Ser 166:83-97

Leis JM (1991) The pelagic stage of reef fishes. In: Sale PF (ed) The ecology of fishes on coral reefs. Academic Press, San Diego, p 183-230

Leis JM, Sweatman HPA, Reader SE (1996) What the pelagic stages of coral reef fishes are doing out in blue water: daytime field observations of larval behavioural capabilities. Mar Freshw Res 47:401-411

Masterson CF, Danilowicz BS, Sale PF (1997) Yearly and inter-island variation in recruitment dynamics of the bluehead wrasse (Thalassoma bifasciatum, Bloch). J Exp Mar Biol Ecol 214:149-166

McCormick MI (1993) Development and changes at settlement in the barbel structure of the reef fish, Upeneus tragula (Mullidae). Environ Biol Fish 37:269-282

McCormick MI (1994) Variability in age and size at settlement of the tropical goatfish Upeneus tragula (Mullidae) in the northern Great Barrier Reef lagoon. Mar Ecol Prog Ser 103:1-15

McCormick MI (1999) Delayed metamorphosis of a tropical reef fish (Acanthurus triostegus): a field experiment. Mar Ecol Prog Ser 176:25-38

McCormick MI, Kerrigan BA (1996) Predation and its influence on the condition of a newly settled tropical demersal fish. Mar Freshw Res 47:557-562

McCormick MI, Molony BW (1992) Effects of feeding history on the growth characteristics of a reef fish at settlement. Mar Biol 114:165-173

McCormick MI, Molony BW (1993) Quality of the reef fish Upeneus tragula (Mullidae) at settlement: is size a good indicator of condition? Mar Ecol Prog Ser 98:45-54

McCormick MI, Molony BW (1995) Influence of water temperature during the larval stage on size, age and body condition of a tropical reef fish at settlement. Mar Ecol Prog Ser 118:59-68

Meekan MG, Fortier L (1996) Selection for fast growth during the larval life of Atlantic cod Gadus morhua on the Scotian Shelf. Mar Ecol Prog Ser 137:25-37

Molony BW, Sheaves MJ (1998) Otolith increment widths and lipid contents during starvation and recovery feeding in adult Ambassis vachelli (Richardson). J Exp Mar Biol Ecol 221:257-276

Montgomery WL, Galzin R (1993) Seasonality in gonads, fat deposits and condition of tropical surgeonfishes (Teleostei: Acanthuridae). Mar Biol 115(4):529-536

Mosegaard H, Svedäng H, Taberman K (1988) Uncoupling the somatic and otolith growth rates in Arctic char (Salvelinus alpinus) as an effect of differences in temperature response. Can J Fish Aquat Sci 45:1514-1524

Nursall JR (1989) Buoyancy is provided by lipids of larval redlip blennies, Ophioblennius atlanticus (Teleostei: Blenniidae). Copeia 3:614-621

OPTIMAS Version 6.1 (1996) Optimas Corporation. Bothell, Washington

Pechenik JA (1990) Delayed metamorphosis by larvae of benthic marine invertebrates: does it occur? Is there a price to pay? Ophelia 32(1-2):63-94

Pechenik JA, Rittschof D, Schmidt AR (1993) Influence of delayed metamorphosis on survival and growth of juvenile barnacles Balanus amphitrite. Mar Biol 115:287-294

Pfeiler E, Luna A (1984) Changes in biochemical composition and energy utilization during metamorphosis of leptocephalous larvae of the bonefish (Albula). Environ Biol Fish 10(4):243-251

Potter IC, Wright GM, Youson JH (1978) Metamorphosis in the anadromous sea lamprey, Petromyzon marinus L. Can J Zool 56:561-570
Robertson DR, Swearer SE, Kaufmann K, Brothers EB (1999) Settlement vs environmental dynamics in a pelagicspawning reef fish at Caribbean Panama. Ecol Monogr 69(2):195-216

Rowe DK, Thorpe JE, Shanks AM (1990) Role of fat stores in the maturation of male Atlantic salmon (Salmo salar) Parr. Can J Fish Aquat Sci 48:405-413

Sander F (1981) A preliminary assessment of the main causative mechanisms of the 'island mass' effect of Barbados. Mar Biol 64:199-205

Schultz ET, Cowen RK (1994) Recruitment of coral-reef fishes to Bermuda: local retention or long-distance transport? Mar Ecol Prog Ser 109:15-28

Searcy SP, Sponaugle S (in press) Early life history traits and survival in two coral reef fishes. Ecology

Secor DH, Dean JM (1989) Somatic growth effects on the otolith-fish size relationship on young pond-reared striped bass, Morone saxatilis. Can J Fish Aquat Sci 46:113-121

Sogard SM (1997) Size-selective mortality in the juvenile stage of teleost fishes: a review. Bull Mar Sci 60(3): 1129-1157

Sokal RR, Rohlf JF (1995) Biometry. The principles and practice of statistics in biological research, 3rd edn. WH Freeman \& Company, New York

Sponaugle S (1994) Recruitment processes of Caribbean coral reef fishes. Dissertation, State University of New York at Stony Brook, NY

Sponaugle S, Cowen RK (1994) Larval durations and recruitment patterns of two Caribbean gobies (Gobiidae): contrasting early life histories in demersal spawners. Mar Biol 120:133-143

Sponaugle S, Cowen RK (1996) Nearshore patterns of coral reef fish larval supply to Barbados, West Indies. Mar Ecol Prog Ser 133:13-28

Sponaugle S, Cowen RK (1997) Early life history traits and recruitment patterns of Caribbean wrasses (Labridae). Ecol Mongr 67(2):177-202

Stobutzki IC, Bellwood DR (1997) Sustained swimming abilities of the late pelagic stages of coral reef fishes. Mar Ecol Prog Ser 149:35-41

Stoner AW, Ray M, Glazer RA, McCarthy KJ (1996) Metamorphic responses to natural substrata in a gastropod larva: decisions related to postlarval growth and habitat preference. J Exp Mar Biol Ecol 205:229-243

Suthers IM (1998) Bigger? Fatter? Or is faster growth better? Considerations on condition in larval and juvenile coralreef fish. Aust J Ecol 23:265-273

Thorrold SR, Milicich MJ (1990) Comparison of larval duration and pre- and post-settlement growth in two species of damselfish, Chromis atripectoralis and Pomacentrus coelestis (Pisces: Pomacentridae), from the Great Barrier Reef. Mar Biol 105:375-384

Thresher RE, Brothers EB (1989) Evidence of intra- and interoceanic regional differences in the early life history of reef-associated fishes. Mar Ecol Prog Ser 57:187-205

Tupper M, Boutilier RG (1995) Effects of conspecific density on settlement, growth and post-settlement survival of a temperate reef fish. J Exp Mar Biol Ecol 191:209-222

Victor BC (1982) Daily otolith increments and recruitment in two coral-reef wrasses, Thalassoma bifasciatum and Halichoeres bivittatus. Mar Biol 71:203-208

Victor BC (1983) Settlement and larval metamorphosis produce distinct marks on the otoliths of the slippery dick, Halichoeres bivittatus. In: Reaka ML (ed) The ecology of deep and shallow coral reefs. National Oceanic \& Atmospheric Administration, Rockville, MD, Symp Ser Undersea Res, Vol 1, p 47-51 
Victor BC (1986) Larval settlement and juvenile mortality in a recruitment-limited coral reef fish population. Ecol Monogr 56(2):145-160

Warner RR, Robertson DR (1978) Sexual patterns in the labroid fishes of the western Caribbean. I. The wrasses (Labridae). Smithson Contrib Zool 254: 1-27

Wellington GM, Victor BC (1989) Planktonic larval duration of

Editorial responsibility: Otto Kinne (Editor), Oldendorf/Luhe, Germany one hundred species of Pacific and Atlantic damselfishes (Pomacentridae). Mar Biol 101:557-567

Wellington GM, Victor BC (1992) Regional differences in duration of the planktonic larval stage of reef fishes in the eastern Pacific Ocean. Mar Biol 113:491-498

Wilkinson L (1992) SYSTAT: the system for statistics, version 5.1. SYSTAT, Inc, Evanston, IL

Submitted: June 7, 1999; Accepted: May 18, 2000

Proofs received from author(s): October 16, 2000 